\title{
Assessing progress towards responsible consumption and production
}

\author{
Daniela Rybárová ${ }^{1, *}$ \\ ${ }^{1}$ University of Economics in Bratislava, Faculty of Business Management, Dolnozemská cesta 1, \\ Bratislava, Slovak republic
}

\begin{abstract}
The success of building sustainable consumption and production depends on creating a sufficient awareness and above all the involvement of all countries in the process of improving the environmental performance of products throughout their life cycle. Awareness and understanding of the social and economic dimension, influences building of sustainable consumption and production in the widest scale and makes it possible to encourage and motivate to socially responsible behavior. The article focuses on summarizing the basic attributes of sustainable consumption and production, as well as on the comparison of the progress of V4 countries in meeting the goal of "Responsible consumption and production" forming part of the Sustainable Development Agenda until 2030. We focus on indicators with quantitative target, where insufficient progress towards the EU target was achieved or there was a movement away from the target. The indicators are Primary energy consumption and Final energy consumption.
\end{abstract}

\section{Introduction}

The challenge today is a quality environment and sustainable development. This can only be achieved by streamlining production and changing consumption patterns [1], enabling optimization of resource use and minimize waste [2]. Problematic of sustainable consumption and production is a broad conception that is integrating application of advanced methods and techniques of business management [3], in all areas, including ecodesign and innovation, sustainable marketing, risk management and strategic management with a focus on sustainable development for the environment.

Based on economic theories, the possibilities of satisfying the needs of either the producer or the consumer are limited only by the influence of market forces [4]. Various economists have pointed out the possibility of abusing your own interests in economic processes [5], US member of institutionalism; who has criticized the materialistic tendency of individuals' efforts of appropriation and not the value creation, which is leading to massive waste of creative human work and of limited resources. Some economists [6] in the broader context are considering whether the purpose of human life is merely the accumulation of wealth, which in terms of exhaustibility of limited resources leads to the

\footnotetext{
* Corresponding author: daniela.rybarova@euba.sk
} 
restriction of resources for the future generations. They point out that there is currently an economic system that is in contradiction with natural laws, expecting someone else to resolve the consequences. In connection with the conditions of sustainable development of human society, the economic theory is faced with questions that need to be answered [7]. These facts lead to the need to develop new concepts of wealth and prosperity, achieved through lifestyle change that will enable a higher standard of living with lower dependency on limited resources.

The term "sustainable development" itself was introduced in 1987 in the report of UN Commission "Our future to all" led by GH Burdtland. The United Nations (UN) has declared fundamental support for sustainable development (SD) at the Conference on Environment and Development in Rio de Janeiro in 1992, at which AGENDA 21 was adopted as a basis for developing SD strategies. Sustainable consumption and production was also part of the SD objectives. In 1994, sustainable consumption and production was defined at the Oslo Symposium, as "use of services and related products that meet basic human needs and provide a better quality of life, minimizing the use of natural resources, hazardous materials as well as releasing pollutants or producing waste throughout the life cycle of services and products into the environment in a way that it will not affect the needs of future generations." In 2015, UN Member States adopted AGENDA 2030, which consists of 17 goals for sustainable development (including sustainable consumption and production) and 169 related milestones that are balancing three aspects of sustainable development - economic, social and environmental [8].

Sustainable development has become the priority of European Union (EU) since the summit of the Council of Europe in Cardiff (June 1998). The European Council summit in Gothenburg (2001) adopted the first Sustainable Development Strategy (SDS) and in 2006 adopted revised Sustainable Development Strategy (SDS) due to the persistency of unsustainable trends in terms of climate change, the use of energy and use of natural resources. The main challenge was to change the currently unsustainable consumption and production models. In 2008, the European Commission issued an Action Plan on Sustainable Consumption and Production (SCP), which included series of proposals on sustainable consumption and production such as eco-design requirements, strengthening of environmental and energy labels, promoting green public procurement, promoting resource efficiency, eco-innovation and promotion of sustainable production and consumption, etc. In 2010 European Council endorsed a strategy for the next period, which was named Europe 2020. In December 2015 European Commission approved EU Action Plan for Circulatory Economy as a tool to achieve goals from AGENDA 2030, particularly Goal 12 "Sustainable Consumption and Production". Subsequently developed strategy Europe 2030 is dealing with long-term visions and focus of sector policies after 2020, where it is assumed that in horizon of 2030, Europeans will need a highly competitive and sustainable social market economy in order to maintain social cohesion and combat climate change. The sustainability of Europe's economic and social model will depend on the ability to restore a dynamic balance between economic, social and environmental dimensions of development. The impact of the nonachievement of the sustainable development goals [9] may expose humanity to forms of global catastrophic risk and existential risk. Some authors [10] intend whether those objectives to support responsible consumption and production.

Sustainable consumption and production have been recognized as an integral part of the Sustainable Development Agenda until 2030. It is identified separately as objective number 12 , and at the same time as a link for some other agreed objectives. Goal 12 "Responsible consumption and production" is divided into 11 indicators with a quantitative target.

Eurostat has been entrusted with the task to monitor regularly progress towards the goals of the 2030 Agenda for Sustainable Development in the EU context. To this end, the 
Eurostat coordinated the preparation of the EU indicators set and has been tasked with its management. It also works out regular statistical monitoring reports on progress towards sustainable development goals in the EU context. Reports are based on a set encompassing 100 indicators, of which 41 are multipurpose indicators, i.e. they are used for monitoring more than just one goal. The set of indicators is open, and it will be regularly reviewed in line with future political developments. New indicators will also be assessed if data sources and methodology are available.

Over the most recent five years of available data [11], the EU made progress towards almost all the 17 sustainable development goals (SDG). Progress in some goals has been faster than in others, and within goals, movement away from the sustainable development objectives also occurred in specific areas. In the article, we focused on the development of indicators of goal 12 ,Responsible consumption and production“.

Insufficient progress towards the EU target under Goal 12 was recorded under the indicators: Primary energy consumption, Generation of waste excluding major mineral wastes and movement away from the EU target was recorded under the indicator Final energy consumption. For further analysis, we selected two of these indicators, Primary energy consumption and Final energy consumption. Data from the Eurostat database will be used.

\section{Methods}

Mathematical methods such as percentage, development index will be used to analyze the indicators, with the base year being 2005. The results will be compared with the targets set by the EU for the given area.

\section{Indicators characteristics:}

Primary energy consumption - the indicator measures the total energy needs of a country excluding all non-energy use of energy carriers (e.g. natural gas used not for combustion but for producing chemicals). "Primary Energy Consumption" covers the energy consumption by end users such as industry, transport, households, services and agriculture, plus energy consumption of the energy sector itself for production and transformation of energies, losses occurring during the transformation of energies (e.g. the efficiency of electricity production from combustible fuels) and the transmission and distribution losses of energy) [11]. Final energy consumption - the indicator measures the energy end-use in a country excluding all non-energy use of energy carriers (e.g. natural gas used not for combustion but for producing chemicals). "Final energy consumption" only covers the energy consumed by end users, such as industry, transport, households, services and agriculture; it excludes energy consumption of the energy sector itself and losses occurring during transformation and distribution of energy [11]

\section{EU goals for Primary and Final energy consumption indicators:}

According to the Directive (EU) 2018/2002 of the European Parliament and of the member States should set their national indicative energy efficiency contributions taking into account that the Union's 2030 energy consumption has to be no more than 1273 Mtoe of primary energy and/or no more than 956 Mtoe of final energy. This means that primary energy consumption in the Union should be reduced by $26 \%$, and final energy consumption should be reduced by $20 \%$ compared to the 2005 levels.

\section{Results}

Insufficient progress towards EU target was recorded for the Primary energy consumption indicator. The development of the indicator in comparison with the base year 
2005 in the V4 countries and for comparison also in the EU (Renewable electricity and sustainable development goals in the Renewable electricity and sustainable development goals in the EU [7] is shown in the following figure (Fig. 1).

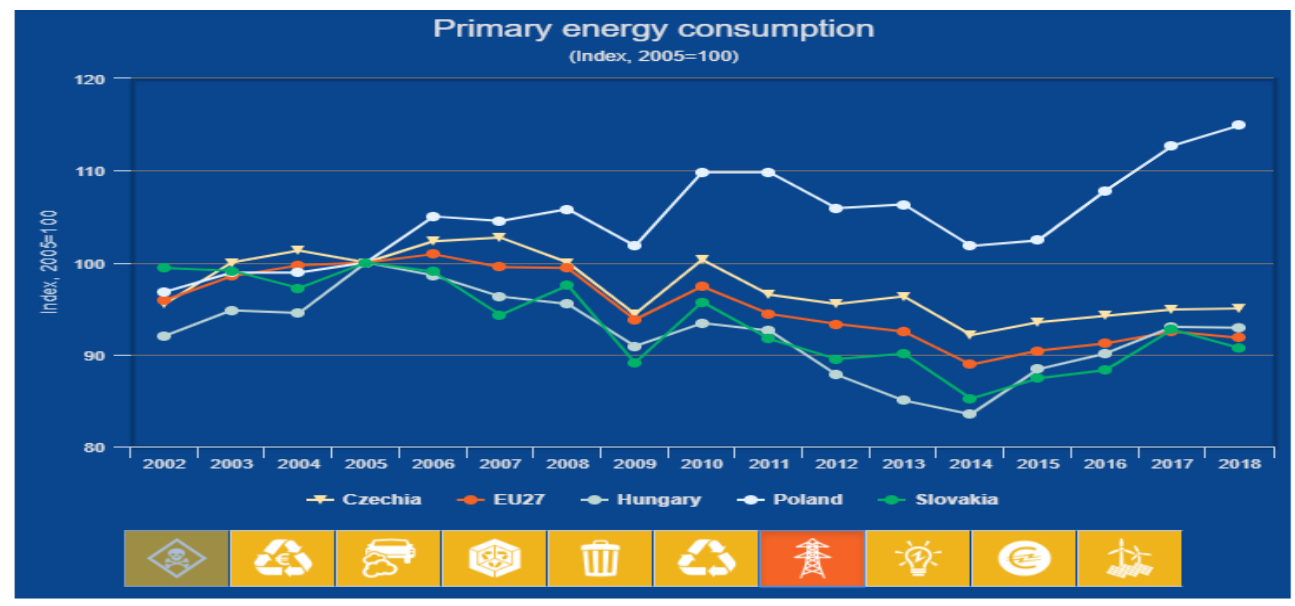

Fig. 1. Primary energy consumption from 2002 to 2018 (index, 2005=100)

Compared to 2005, primary energy consumption was lower each year only in the Slovak Republic and Hungary. Within the EU, there was an increase only in 2006, but in recent years consumption has shown a declining trend. In the Czech Republic, primary energy consumption exceeded the value of 2005 in 2006, 2007 and 2010. In recent years, its amount is lower. In the Republic of Poland, unlike the others, primary energy consumption in each subsequent year is even higher compared to 2005. The positive development of primary energy consumption in the other countries analyzed ended in 2014, when consumption has been on the rise, although not exceeding 2005 levels. These facts are related to the development of national economies after the end of the financial crisis, as well as its second wave in 2012. The percentage change in primary energy consumption is shown in the following table (table 1).

Table 1. Primary energy consumption (percentual change, 2005=100)

\begin{tabular}{|l|r|r|r|r|r|r|r|r|r|r|r|r|r|r|}
\hline geoltime & $\mathbf{2 0 0 5}$ & $\mathbf{2 0 0 6}$ & $\mathbf{2 0 0 7}$ & $\mathbf{2 0 0 8}$ & $\mathbf{2 0 0 9}$ & $\mathbf{2 0 1 0}$ & $\mathbf{2 0 1 1}$ & $\mathbf{2 0 1 2}$ & $\mathbf{2 0 1 3}$ & $\mathbf{2 0 1 4}$ & $\mathbf{2 0 1 5}$ & $\mathbf{2 0 1 6}$ & $\mathbf{2 0 1 7}$ & $\mathbf{2 0 1 8}$ \\
\hline $\begin{array}{l}\text { EU (28 } \\
\text { countries) }\end{array}$ & 100 & 0,6 & -1 & $-1,2$ & -7 & $-3,3$ & $-6,8$ & $-7,4$ & $-8,4$ & $-12,1$ & $-10,7$ & $-10,2$ & $-9,2$ & $-9,8$ \\
\hline Czechia & 100 & 2,3 & 2,7 & 0 & $-5,6$ & 0,3 & $-3,5$ & $-4,5$ & $-3,7$ & $-7,9$ & $-6,5$ & $-5,8$ & $-5,1$ & -5 \\
\hline Hungary & 100 & $-1,4$ & $-3,7$ & $-4,5$ & $-9,1$ & $-6,6$ & $-7,4$ & $-12,2$ & -15 & $-16,5$ & $-11,6$ & $-9,9$ & -7 & $-7,1$ \\
\hline Poland & 100 & 5 & 4,5 & 5,8 & 1,8 & 9,8 & 9,8 & 5,9 & 6,3 & 1,8 & 2,4 & 7,8 & 12,7 & 14,9 \\
\hline Slovakia & 100 & -1 & $-5,7$ & $-2,5$ & $-10,9$ & $-4,3$ & $-8,3$ & $-10,5$ & $-9,9$ & $-14,8$ & $-12,6$ & $-11,7$ & $-7,3$ & $-9,3$ \\
\hline
\end{tabular}

Since the EU's goal is that primary energy consumption in the Union should be reduced by $26 \%$, compared to the 2005 levels, the decrease (with the exception of the Republic of Poland) by 5 to $10 \%$ is insufficient to meet the objective.

Movement away from the EU target shows the indicator Final energy consumption, which, unlike the previous indicator excludes energy consumption of the energy sector itself and losses occurring during the transformation and distribution of energy. Final energy consumption should be reduced by $20 \%$ compared to the 2005 levels. We therefore examined its development in the V4 countries and in the EU. 


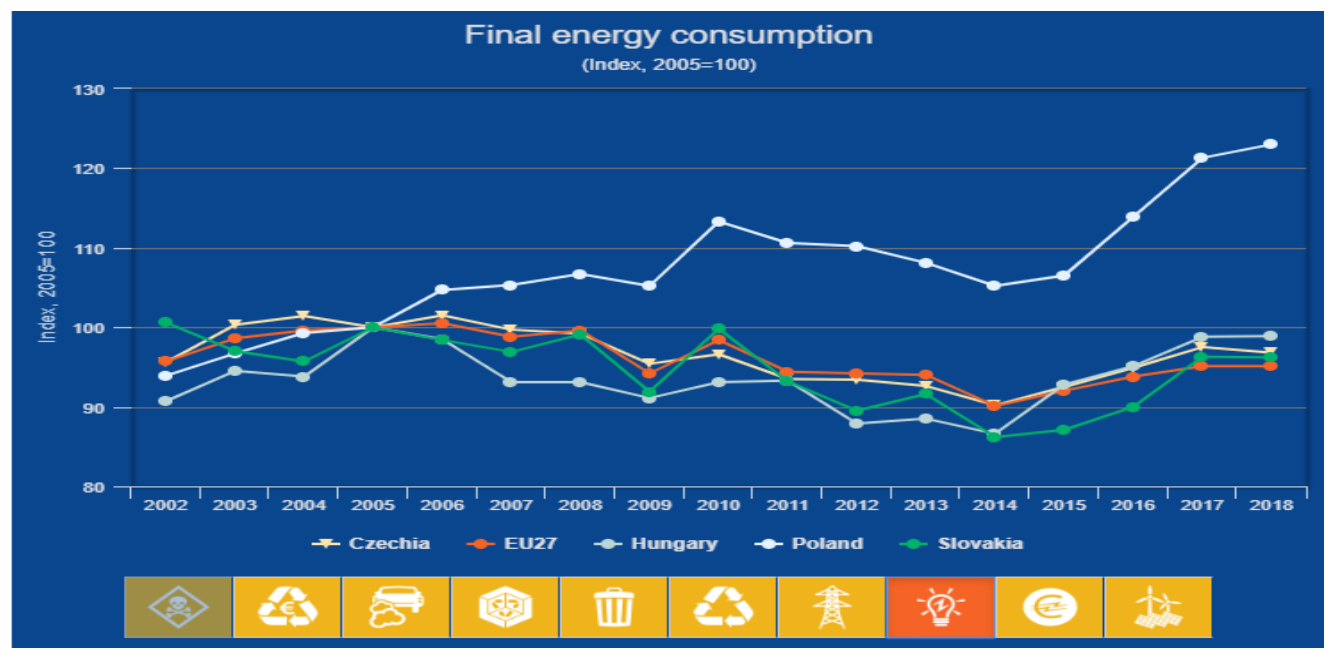

Fig. 2. Final energy consumption from 2002 to 2018 (index, 2005=100)

Final energy consumption of the V4 countries and the EU in 2018 approached the value from 2005. In the Republic of Poland, the consumption has even been on the rise throughout the analyzed period since 2005. The percentage changes in the amount of consumption are shown in the following table.

Table 2. Final energy consumption (percentual change, 2005=100)

\begin{tabular}{|l|r|r|r|r|r|r|r|r|r|r|r|r|r|r|}
\hline geoltime & 2005 & 2006 & 2007 & 2008 & 2009 & 2010 & 2011 & 2012 & 2013 & 2014 & 2015 & 2016 & 2017 & 2018 \\
\hline $\begin{array}{l}\text { EU (28 } \\
\text { countries) }\end{array}$ & 100 & 0,3 & $-1,4$ & $-0,7$ & $-6,3$ & $-2,3$ & $-6,7$ & $-6,5$ & $-6,6$ & $-10,6$ & $-8,7$ & -7 & $-5,9$ & $-5,8$ \\
\hline Czechia & 100 & 1,5 & $-0,3$ & $-0,8$ & $-4,6$ & $-3,4$ & $-6,5$ & $-6,6$ & $-7,4$ & $-9,8$ & $-7,5$ & $-5,1$ & $-2,5$ & $-3,2$ \\
\hline Hungary & 100 & $-1,5$ & $-6,9$ & $-6,9$ & $-8,9$ & $-6,9$ & $-6,7$ & $-12,1$ & $-11,5$ & $-13,4$ & $-7,2$ & $-4,9$ & $-1,2$ & $-1,1$ \\
\hline Poland & 100 & 4,7 & 5,3 & 6,7 & 5,2 & 13,3 & 10,6 & 10,2 & 8,1 & 5,2 & 6,5 & 13,9 & 21,3 & 23 \\
\hline Slovakia & 100 & $-1,6$ & $-3,1$ & $-0,9$ & $-8,1$ & $-0,2$ & $-6,8$ & $-10,5$ & $-8,4$ & $-13,8$ & $-12,9$ & -10 & $-3,7$ & $-3,8$ \\
\hline
\end{tabular}

As final energy consumption in the Union should be reduced by $20 \%$ compared to the 2005 levels, we can speak of a positive development only until 2014. Since that year, consumption has grown and in 2018 approached the consumption from 2005, when except for the Republic of Poland, consumption is only $1 \%$ to $6 \%$ lower. With this indicator, it can be stated that there has been a movement away from the EU target.

Although the Slovak Republic, together with the Czech Republic, also show insufficient fulfillment of the given indicators, they are closest to the EU average. Based on the given analyzes, the Republic of Poland achieved the worst results as the indicators of primary and final energy consumption show an increasing tendency compared to 2005. We therefore further examined the state of final energy consumption measured in tons of oil equivalent per capita in 2018 compared with other EU countries (picture) 


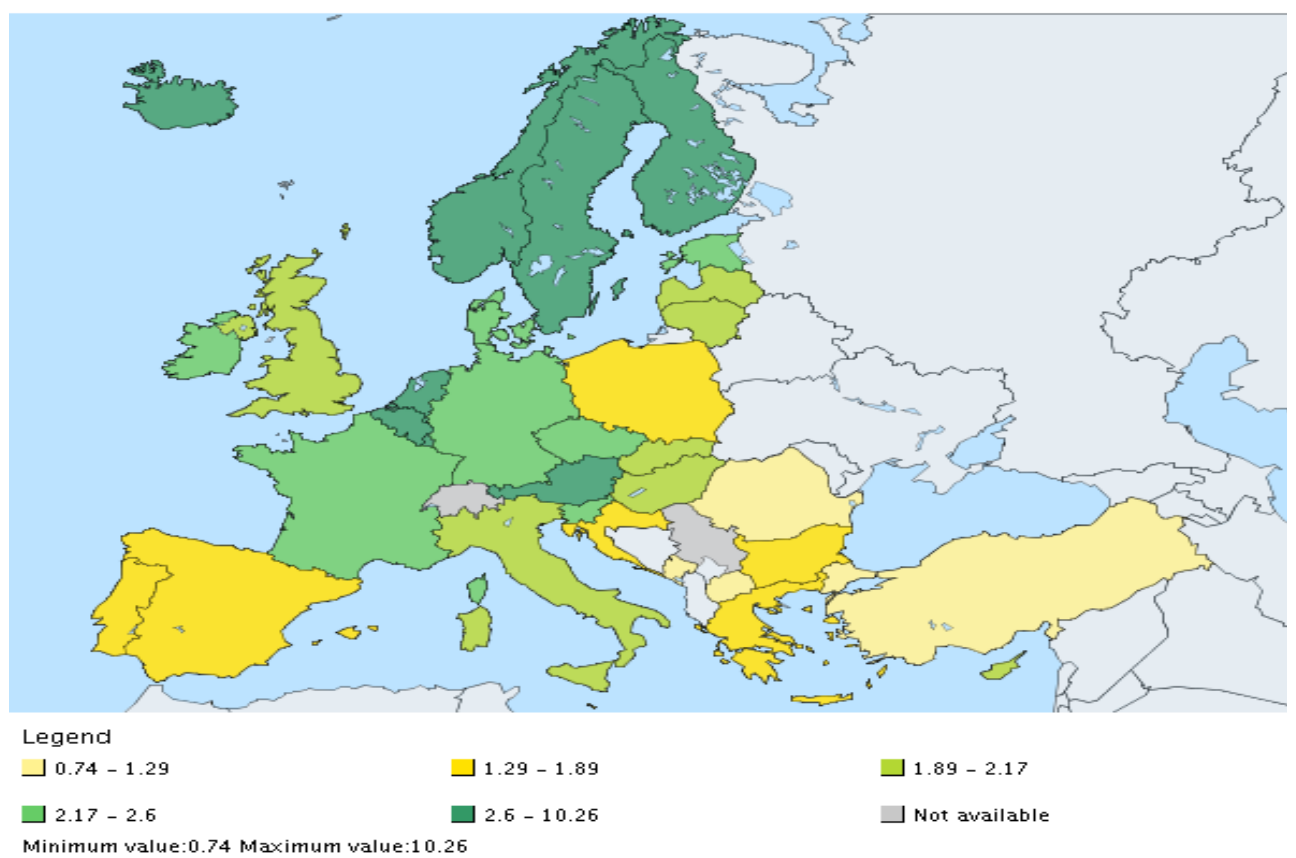

Fig. 3. Final energy consumption, 2018 (Tons of oil equivalent per capita)

The map of final energy consumption for 2018 points to the fact that of the V4 countries, the Republic of Poland has the lowest final energy consumption in tons of oil equivalent per capita, which partly explains the steady growth in consumption compared to 2005. Slovak republic and Hungary are included in the same group and reach the EU average. The Czech Republic has the highest final energy consumption of the V4 countries.

The final and primary energy consumption indicators are clearly linked to the development of the economies of individual countries, we analyzed the development of the economies of the V4 countries using gross domestic product at market prices, where due to the change in statistical reporting we have consistent data since 2008 , we chose this year as the base year.

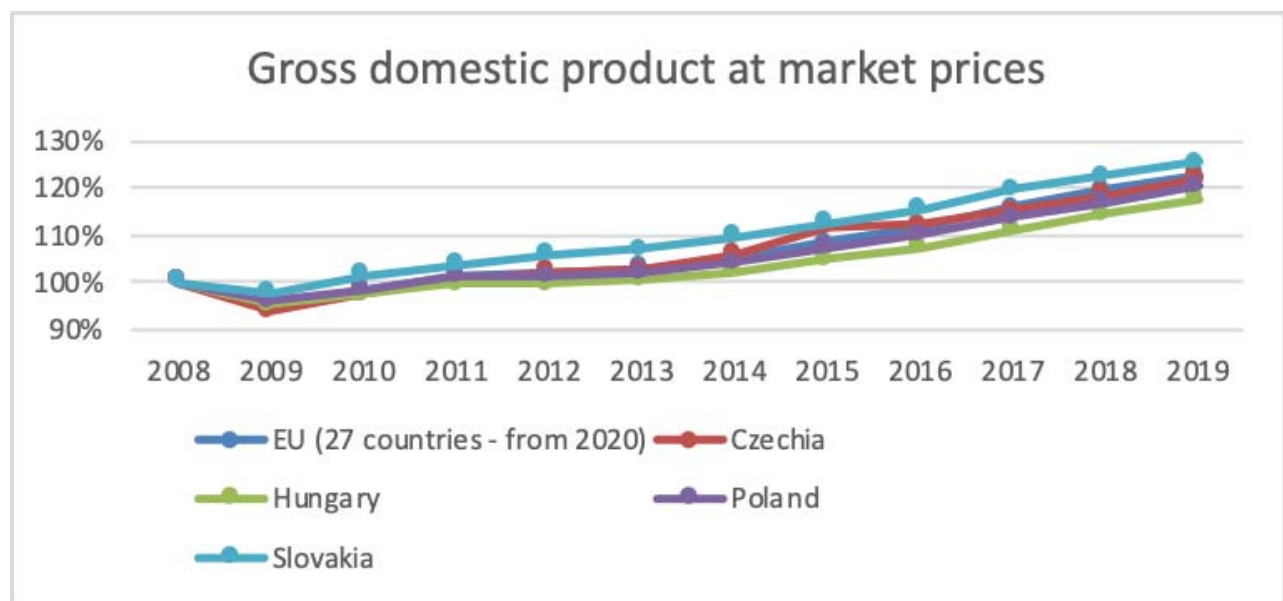

Fig. 3. Gross domestic product at market prices from 2008 to 2019 
The development of gross domestic product at market prices was affected by the financial crisis and in 2009 there was a significant decline. Subsequently, in the years 2011 to 2014, it slowed down its growth. After 2014, there is already relatively stable growth. This fact also affected the fulfillment of the analyzed indicators. Among the V4 countries, the lowest growth was again recorded in the Republic of Poland, which means that this growth was also accompanied by an increase in final and primary energy consumption. However, the Slovak Republic, which has the highest GDP growth and showed the best results in meeting the analyzed indicators, was able to reduce final and primary energy consumption the most of the V4 countries. There was a decrease in the energy intensity of the Slovak economy.

According to the Statistical Office of the Slovak Republic for the years 2005 - 2018, the energy intensity of the Slovak economy decreased by $42.9 \%$. This positive trend is the result of GDP growth expressed in p.c.15, which increased by about $57.9 \%$ over the same period and a decrease in gross domestic energy consumption, which, on the contrary, decreased by $9.8 \%$ over the observed period. Despite the favorable trend, in 2017 the Slovak Republic had the seventh highest energy intensity in the EU 28. There was a 3.6\% year-on-year decrease in energy intensity in 2018 , which was mainly due to a $4.0 \%$ yearon-year increase in GDP. Energy intensity in selected sectors of the Slovak Republic according to final energy consumption had a declining trend in all monitored sectors from 2005 to 2018 . The largest decreases were recorded in the agricultural sector $(75.9 \%)$ and in the industrial sector $(55.0 \%)$, followed by the household sector $(19.7 \%)$. The smallest decrease was achieved in the transport sector (9.1\%). Energy intensity also decreased in all sectors in the year-on-year comparison.

\section{Conclusion}

At national level, well-designed national policy frameworks and instruments are needed to enable a fundamental shift towards sustainable consumption and production patterns. The strategic goal of the energy policy of the Slovak Republic is to achieve competitive low-carbon energy ensuring a secure, reliable and efficient supply of all forms of energy at affordable prices, considering consumer protection and sustainable development. Energy policy [12] is complemented by an energy security strategy, the main objectives of which are: a reliable, environmentally friendly and economically efficient energy supply; increasing the use of renewable energy sources, in particular watercourses, biomass, geothermal energy and solar energy; use of domestic primary energy sources for the production of electricity and heat on an economically efficient principle in accordance with the raw materials policy - coal and domestic reserves of uranium ores to reduce dependency on energy imports, as well as reducing energy and raw material intensity of the Slovak economy.

Economists should focus on finding good solutions [13] to managers and decision makers to achieve energy cost savings without sacrificing the productivity which can contribute to sustainable development of the manufacturing industry. All companies within their business models should also contribute to reducing energy intensity $[14,15]$. New models of sustainable consumption [16] and production must emphasize the creation of higher added value with fewer inputs, reduced costs and minimized environmental impact. It is beneficial for companies themselves, because they can reduce their operating costs and reduce their dependence on minerals.

\section{Acknowledgment}

This paper is an output of the science project VEGA $\check{c}$. 1/0708/20 ,Socio-economic determinants of sustainable consumption and production in terms of impact on performance and competitiveness of enterprises" - project share is $100 \%$; 


\section{References}

1. M. E. Silva, M. D. Figueiredo. Practicing sustainability for responsible business in supply chains. Journal Of Cleaner Production, 251, 119621. (2020)

2. G. K. Amoako. A conceptual framework: Corporate environmental management activities and sustainable competitive. Management Of Environmental Quality, 31(2), 331-347. (2020)

3. J. Elbaz, S. Iddik. Culture and green supply chain management (GSCM): A systematic literature review and a proposal of a model. Management Of Environmental Quality, 31(2), 483-504. (2020)

4. A. Smith. Pojednání o podstatě a původu bohatství národi̊. (Liberální institut, Praha, 2016.

5. T. Veblen. Teorie zahálčivé třídy. (Sociologické nakladatelství, Praha,1999)

6. P.M. Senge, B. Smith, N. Kruschwitz, J. Laur, S. Schley. The Necessary Revolution: How Individuals and Organizations are Working Together to Create a Sustainable World. (Nicholas Brealey Publishing, London, 2010)

7. M. Uramová et al. Hospodárska politika. (Univerzita Mateja Bela, Ekonomická fakulta, Banská Bystrica, 2003).

8. P. Chowdhury, S. K. Paul. Applications of MCDM methods in research on corporate sustainability: A systematic literature review. Management Of Environmental Quality, 31(2), (2020)

9. T. Cernev, R. Fenner. The importance of achieving foundational Sustainable Development Goals in reducing global risk. Research \& Management Science. 115, 102492, (2020)

10. J. Gunawan, P. Permatasari, C. Tilt. Sustainable development goal disclosures: Do they support responsible consumption and production? Journal Of Cleaner Production, 246, 118989. (2020)

11. European Union. Sustainable development in the European Union - Monitoring report on progress towards the SDGs in an EU context. (Publications Office of the European Union, Luxembourg, 2019)

12. Ministerstvo hospodárstva SR. Integrovaný národný energetický a klimatický plán na roky 2021-2030. (Bratislava, október 2019)

13. M.H. Ho, F. Hnaien., F. Dugardin. Electricity cost minimisation for optimal makespan solution in flow shop scheduling under time-of-use tariffs. International journal of production research. 10.1080/00207543.2020.1715504 (2020)

14. R. B. Swain, A. Karimu.. Renewable electricity and sustainable development goals in the EU. World Development. 125, 104693. (2020)

15. Z. Fu, R. Li. The contributions of socioeconomic indicators to global PM2.5 based on the hybrid method of spatial econometric model and geographical and temporal weighted regression. Science of the total environment. 703, 135481 (2020)

16. R. Šlosár, Š. Majtán, P. Štetka, N. Grisáková. Vizuálne podnety a responzívne správanie spotrebitelov. (Wolters Kluwer, Praha, 2019) 